\title{
Dictynna
}

Dictynna

Revue de poétique latine

\section{Barbarian variations : Tereus, Procne and Philomela in Ovid (Met. 6.412-674) and Beyond}

\author{
Ingo Gildenhard and Andrew Zissos
}

\section{(2) OpenEdition}

1 Journals

\section{Electronic version}

URL: http://journals.openedition.org/dictynna/150

DOI: 10.4000/dictynna.150

ISSN: 1765-3142

\section{Electronic reference}

Ingo Gildenhard and Andrew Zissos, « Barbarian variations : Tereus, Procne and Philomela in Ovid (Met. 6.412-674) and Beyond », Dictynna [Online], 4 | 2007, Online since 25 November 2010, connection on 10 September 2020. URL : http://journals.openedition.org/dictynna/150 ; DOI : https://doi.org/ 10.4000/dictynna.150

This text was automatically generated on 10 September 2020 .

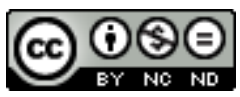

Les contenus des la revue Dictynna sont mis à disposition selon les termes de la Licence Creative Commons Attribution - Pas d'Utilisation Commerciale - Pas de Modification 4.0 International. 


\section{Barbarian variations : Tereus, Procne and Philomela in Ovid (Met. 6.412-674) and Beyond}

Ingo Gildenhard and Andrew Zissos

\section{Introduction : Ovid's Eschaton?}

1 At the opening of Christoph Ransmayr's The Last World - a novel with an Ovidian repertory Maximus Messalinus Cotta, one of the addressees of Ovid's exile poetry and, in the novel, a literary aficionado, is on his way to the Black Sea. ${ }^{1} \mathrm{~A}$ rumor has reached Rome that Naso has vanished in the wilderness around Tomi, and Cotta is determined to find out what has become of his friend. At the same time, he is driven by the hope of finding a manuscript of the Metamorphoses. For Ovid, so the novel has it, has succeeded where Virgil failed, incinerating the lone public copy of his epic masterpiece in a fit of pique at Augustus before going into exile.

2 If, in The Last World, Rome is in the grip of a whimsical tyrant who presides over an anonymous and relentlessly efficient state bureaucracy, the oppressive order of the capital fades when set against the grim atmosphere in Tomi. Located "in the middle of nowhere", it is a "town of iron", fit only for inhabitants of a degenerate age. The novel chronicles Cotta's adventures in this ghastly realm of moral and ecological decay. At first Ransmayr's protagonist does not realize that in the pernicious environment of Tomi the figments of Ovid's literary imagination have come to life - more often than not to appalling effect. ${ }^{2}$ Through his efforts to solve the enigmas surrounding Ovid's disappearance, Cotta becomes an involuntary character in the mythic narratives of the poem he is pursuing. The quest for Ovid and his epic - aided by such suggestive intermediaries as Pythagoras, Naso's former servant, the town-whore Echo, or the gossip-prone shopkeeper Fama - becomes increasingly frenzied until Cotta is in danger of losing his bearings in a world beyond the purview of common sense. Only in chapter fifteen, the last of the book, which Ransmayr invests with a peculiar kind of 
eschatology, does an enlightening trauma suspend Cotta's vertiginous descent into the madness of Ovidian myth. ${ }^{3}$

3 The catalyst for the moment of revelation is a close encounter with the rebarbative powers of Ovidian art. Just as the nonplussed Cotta begins to despair of solving the hermeneutic puzzles posed by the various local dramatis personae, he is accidentally drawn into the affairs of the town butcher Tereus and his dysfunctional household, clearly modeled on the Tereus, Procne and Philomela episode of Met. 6. In Ransmayr's reworking of what is surely the most gruesome tale of Ovid's epic, his character becomes a participant-observer in a grim sequence involving rape, mutilation, infanticide, and cannibalism. Before Ovid this disturbing material had been capaciously rendered by Attic and Roman playwrights ${ }^{4}$ Cotta's reaction to it is, appropriately, a moment of lucidity. The series of atrocities shocks him out of his delusions, prompting a scene of terminal (dis)closure in which he undergoes the prescribed anagnorisis. Cotta begins to understand that the world of the poem stands for its elusive creator, and that the literary cosmos of the text he is seeking to recover is in fact a consuming artifact on the verge of absorbing him too. Watching the ghastly events with mounting dismay, Cotta realizes that the only way to meet the poet is to enter his poem, and he accepts this as his destiny - which had been anticipated in "the scraps and pennants" of the Metamorphoses he had discovered littered across the squalid landscape that is Ransmayr's Tomi. ${ }^{5}$ In this shrewdly crafted denouement, Cotta thus morphs into a symbol of the act of reading, an act whereby author and reader find each other in the territory mapped out by the text.

4 As Ransmayr's culminating gesture to the Metamorphoses, Cotta's acquisition of metaliterary awareness offers an analogue to Ovid's parting words, which envision the author's apotheosis through the everlasting reception of his poem, a form of immortality predicated on countless readers immersing themselves in his text. ${ }^{6}$ Yet the ending of The Last World transcends the genteel urbanity of metapoetic sophistication. While the intertextual pas de deux with the triumphant sphragis of the Metamorphoses may be artistically scintillating, it also contains a mortifying subtext. Unlike Ovid's epilogue, which gestures towards heaven (Met. 15.875-6 super ... astra ferar), Ransmayr's reprise does not direct our attention skywards but to hell on earth. Of all the Ovidian myths that might have triggered Cotta's insight into his destiny, Ransmayr opted for a tale of singularly grotesque savagery. This choice suggests that, in Ransmayr's view, the most profound understanding of Ovid and his work derives from a close encounter with the most offensive of his literary fantasies. In The Last World, the viewing of inexplicable brutalities turns out to be strangely cathartic in that it restores to a Cotta teetering on the brink of insanity a sense of reality; but the fact that special insight seems contingent upon the vicarious experience of sociopathic violence produces a disturbing collusion of privileged knowledge and (the representation of) barbarity.

Given the novel's broader literary agenda, this epistemology makes sense. After all, Ransmayr's tale amounts to a rewriting of the Metamorphoses in the bleak spirit of Ovid's own Tristia and Epistulae ex Ponto. The defining characteristics of the discors machina that results from the fusion of Ovid's epic with his exile poetry are bitterness and hatred, spoiled beauty and destructive passion, an all-pervading sense of doom and a seeming impermeability to pain and suffering - quite apart from the frequent ecological disasters that serve as cosmic backdrop to the human plots. Small wonder, then, that Ransmayr should turn the gruesome menage à trois of Tereus and the two 
daughters of Pandion into the key to understanding Ovid's literary imagination. His apocalyptic novel gains coherence through the appearance of Tereus and his victims, whose story constitutes a culminating moment of horror in The Last World.

6 It is more difficult to invoke this kind of 'functional' argument to explain the presence of such troubling material in the Metamorphoses itself. The epic repeatedly registers those characteristically 'Ovidian' qualities of lighthearted wit, droll irony, and willful humor that Ransmayr has systematically expunged from his 'Ovidian repertory'. Even in the episode of Tereus, Procne and Philomela, where readers might deem it illmatched to the chosen subject matter, stylistic sport is of the essence. " "In the tradition of Western literature", says Amy Richlin à propos, "[Ovid's] influence has been great, yet even in his lifetime critics found his poetry disturbing because of the way he applied his wit to unfunny circumstances." ${ }^{\prime}$ Whether Seneca and Quintilian, Ovid's earliest noteworthy critics, felt genuine moral outrage at his gruesome wit or his poetry merely offended against their notions of aesthetic propriety remains a subject for debate. Yet frissons of content and form are an abiding hallmark of Ovidian poetics, and negotiating those two levels remains central to the reception of his text.

7 It is also worth noting that where critics tend to see problems, writers have often sensed creative possibilities. TheLast World is but one of numerous recent additions to a long series of literary engagements with this episode that includes Chretien de Troyes' Philomena et Progne, Chaucer's Legend of Good Women, Gower's Confessio Amantis, and Gascoigne's The Complainte of Phylomene. ${ }^{9}$ Playwrights in particular have embraced this part of the Metamorphoses as a seemingly irresistible source of inspiration. A not insignificant amount of carnage on the Western stage harks back to the bloodshed of the house of Tereus. Ovid's tale represents, if not the fons et origo, then the crucial tributary to a theatrical tradition that concerns itself, often in obsessive detail, with the performance of human atrocities..$^{10}$ Shakespeare above all, but also Seneca, Gregorio Correr, and more recently, Timberlake Wertenbaker and Sarah Kane (among others) have reworked Ovid's version of the Tereus myth. ${ }^{11}$ From the point of view of reception, this part of the Metamorphoses has acquired an archetypal status, mediating for the Western stage the obsession of Athenian drama with the theme of violent transgression. ${ }^{12}$

8 The privilege that the history of reception accords to Ovid's Tereus, Procne and Philomela coincides with the special place the story holds in the narrative economy of the Metamorphoses. It is here that Ovid radically expands the literary and thematic horizons of his poem, fleshing out new, disturbing possibilities on the level of poetics and anthropology. The episode marks a shift from the realm of (divine) myth, in which a central role is ascribed to assorted olympian dramatis personae, to the world of human geopolitics, whereby different cities, states, or cultures wrangle with one another for ascendancy. ${ }^{13}$ This transition follows generic prescriptions : "The shift from a history of the gods to a history of humans is deeply engrained in epic as a genre, and indeed in the Greek imagination more generally. It is a gradual and complex shift which is never complete and always remains open to modifications." ${ }^{14}$ The tale thus marks, despite its chaotic violence and culminating social dissolution, a specific stage in the evolution of the cosmos (and Ovid's textual universe) on its path to Rome. In its horrific fusion of Athenian culture and Thracian barbarity, it also contributes to the broadly unflattering delineation of Greek civilization that is an abiding thematic concern of the Metamorphoses. ${ }^{15}$ 
In what follows, we focus on four interrelated features of Ovid's text that have attracted the attention of subsequent artists, but have yet to find full acknowledgement and appreciation in the scholarly literature $:{ }^{16}$ (1) a figuring of hell on earth; (2) a poetics of perversion ; (3) an aesthetics of vengeance ; and (4) an entropy of culture.

\section{Hell on earth}

The first half of Met. 6 continues the dominant theme of the previous book: punitive action taken by Olympian deities against hybristic humans. Minerva transforms Arachne (6.1-145), Apollo and Diana bereave and petrify Niobe (6.146-312), Latona turns the Lycian peasants into frogs (6.313-81); Apollo skins Marsyas (6.382-400). ${ }^{17}$ After an ominous interlude featuring a brief account of Pelops (6.401-11), the narrative resumes with Tereus and Athens, a city whose origins have already been treated. The latter part of Book 2 rehearses a cycle of ktisis legends, and the ecphrastic elaboration of Minerva's tapestry in the Arachne episode renders that goddess' primordial competition with Poseidon for divine patronage of the city. But whereas the earlier episodes deal with mythic origins, Ovid now moves forward in time : in a proto-historical gesture, Tereus is said to have relieved the city from a barbarian invasion. ${ }^{18}$ This reference to human geopolitics coincides with a shift in the supernatural dimension of Ovid's narrative. Tereus may trace his lineage back to Mars, but in this episode the Olympian deities are, for the first time in the Metamorphoses, made conspicuous by their absence. ${ }^{19}$

11 Other divine forces take their place. While the plot focuses on how human beings interact with each other, Ovid has included both explicit and implicit references to the Furies in this narrative stretch, inviting us to interpret the tale of Tereus, Procne, and Philomela as a figuring of hell on earth. Their first appearance in particular, which occurs in the decidedly inauspicious description of the wedding between Tereus and Procne, has programmatic force :

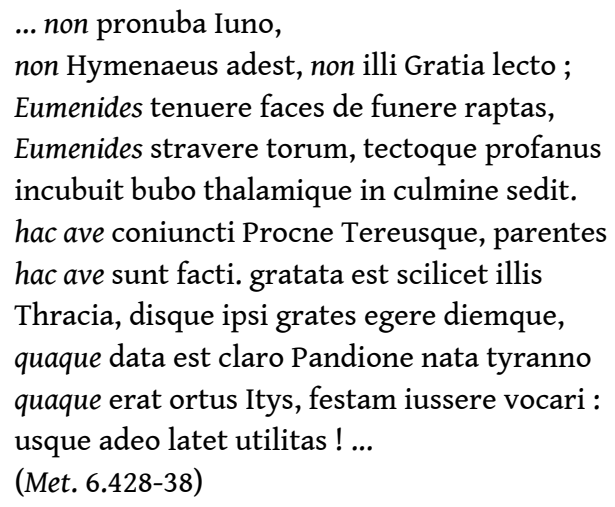

The passage, with its quasi-strophic design (achieved by the anaphora of Eumenides, hac ave and quaque, set apart by one line each, as well as the concluding gnome usque adeo latet utilitas! marking off the prologue from the actual narration) recalls the opening of a hymn. ${ }^{20}$ In effect, Ovid has recreated within an epic narrative format an invocation of the Eumenides, figured as hellish inversions of Hymenaeus or Juno pronuba. ${ }^{21}$ Rather than the latter, it is the Furies who serve as divine chaperones, presiding over the wedding celebrations as well as the birth of Itys. ${ }^{22}$ The stylized sequence thus offers a chilling advertisement of the gruesome turn the narrative will presently take : from the very beginning, the tale has the stench of death about it. 

break loose in Ovid's narrative. The use of the owl as a sinister portent recalls its genesis in the previous book, where Proserpina transformed Ascaphalus into a bubo since he (and only he) testified to her consumption of the pomegranate. The formulation profanam ... avem (5.543-4) is recalled at 6.431-2 profanus ... bubo (continued by hac ave, hac ave in 433-4); and the conclusion of the earlier passage prefigures the bird's role in the Tereus episode: foedaque fit volucris, venturi nuntia luctus, / ignavus bubo, dirum mortalibus omen (5.549-50). The bubo, a bird that came into being in hell, has, in addition to its nether associations, a connection with evil and human suffering. ${ }^{23}$

After their explicit invocation, the Furies continue to register in sublimated form. Thus throughout Tereus' stay in Athens, images of fire, boiling and burning dominate the narrative. ${ }^{24}$ All of those images have, naturally, a great affinity with the semantic field of love : Cupid tends to set his victims on fire; yet they also figure large within the realm of Hell. Torches in particular are the characteristic accoutrement of the Furies, ${ }^{25}$ just as the imperceptible infiltration of hearts and minds with fiery poison is their distinctive modus operandi. An intertextual connection with Virgil's Aeneid in one of Ovid's inflammatory passages leaves no doubt that hellish forces are here indeed at work. From 6.465-6 (et nihil est quod non effreno captus amore / ausit, nec capiunt inclusas pectoral flamas) it appears that Amor has taken control of Tereus. But the passage also harks back to Amata's encounter with Allecto in Aeneid 7, where the Latin queen slowly succumbs to the Fury's lethal poison: necdum animus toto percepit pectore flamman, says Virgil at one point in the drawn-out process (Aen. 7.356). By recalling this highly resonant Virgilian intertext, Ovid peppers his own erotic idiom with hellish undertones, making clear that the violent forces raging within Tereus' breast belong to the spheres of Amor as well as the Underworld.

The pattern of infernal contamination is also evident in the lengthy procedure of vengeance against Tereus. If in Athens the Furies disguised their presence under a veneer of erotic furor, in Thrace they take cover behind Dionysiac revelry. Procne sets out to rescue her sister during a night of Bacchic festivities :26

Tempus erat quo sacra solent trieterica Bacchi

Sithoniae celebrare nurus : nox conscia sacris.

nocte sonat Rhodope tinnitibus aeris acuti ;

nocte sua est egressa domo regina deique

ritibus instruitur furialiaque accipit arma

...

concita per silvas turba comitante suarum

terribilis Procne furiisque agitata doloris,

Bacche, tuas simulat ...

(Met. 6.587-96)

The Dionysian milieu is unquestionably pertinent as a ritual domain - and textual locus - for the unleashing of unbounded female violence. Indeed, Euripides' Bacchae supplies a partial tragic paradigm for what is to unfold, above all in the ritualized murder and dismemberment of son by mother. ${ }^{27}$ But the delusional Agave is a far cry from the hyper-conscious Procne. A more pertinent dramatic precursor is Euripides' Medea, whose eponymous heroine shares with Procne the deliberate choice of infanticide as vengeance against a reprobate spouse and the phallocratic social order that facilitates his offence. ${ }^{28}$ Moreover, although Procne is dressed up as a maenad in this scene, Ovid makes clear that her Bacchic ecstasy is feigned, a veneer, which, on the level of plot, 
merely conceals her real intentions and, on the level of poetics, indicates the presence of a different narrative force : the Furies. The nocturnal setting is suggestive in itself, and the gemination nocte ... nocte recalls the triple anaphora at the tale's hellish incipit. ${ }^{29}$ But it is once again an allusive gesture to the infernal context of Aeneid 7 that drives the point home :

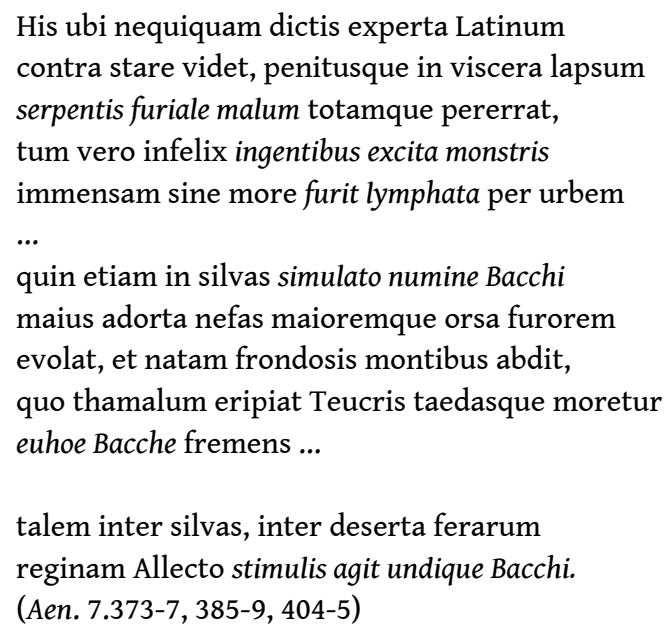

While these verses invoke the Dionysiac frenzy of the tragic theater and contain literary gestures to tragic scripts, ${ }^{30}$ it is the fury Allecto who coordinates the Bacchic outcries and activities. She stimulates Amata to act out the role of a maenad. This simulation of Dionysiac behavior serves as a model for both Ino's and Athamas' tragic delusions in Met. 4 and Procne's trickery in Met. $6 .{ }^{31}$ How skillfully Ovid dresses Procne's hellish intent in a Bacchic guise may be gleaned from Bömer's discussion of Procne's furialia... arma (6.591). The indefatigable Ovidian commentator notes that prior to Ovid furialis is used only in reference to the Furies, and that in the present passage we have an apparently unique transference to the furor bacchantium. ${ }^{32}$ But the intertextual engagement with Virgil's Amata scene indicates a more complex state of affairs. Both Virgil and Ovid (and also Ovid via Virgil) take up an idea prefigured in Attic tragedy, namely the conflation of Bacchic and hellish furor, which manifests itself in such formulations as "Bacchants from Hell", and raises questions about the origins of criminal passions. This conflation tends to occur in those places where sociopathic violence, such as infanticide, the ritual murder of children, intra-marital slaughter, or cannibalism, goes beyond even the rather wide remit of transgressions for which Dionysus is prepared to take responsibility. ${ }^{33}$ The surviving tragic script that explores this configuration most insistently is Euripides' Hecuba, a play not coincidentally set in Thrace. $^{34}$

18 As the narrative progresses, Procne and Philomela become increasingly assimilated to Furies. Once reunited, they form a ruthless sisterhood determined to avenge a crime committed within the family - an early specialization of the Eumenides. The transformation registers in Philomela's triumphant appearance before the horrified Tereus, so drastically changed from her mesmerizing beauty at the beginning of the episode : sicut erat sparsis furiali caede capillis, / prosiluit (6.657-8). Tereus' invocation of the 'snaky Sisters' (vipereasque ciet Stygia de valle sorores, 6.662) is therefore darkly ironic..$^{35}$ Overall, a ring composition emerges. Given that the standard structure of a narrative hymn consists in the tripartite division 'initial invocation - aretalogy - 
concluding invocation', the entire episode of Tereus, Procne, and Philomela becomes something like a hymnic celebration of the powers of the Eumenides.

Futile invocations of the gods above, often combining the vain appeal to absent or unheeding divinities with the tragic theme of human improvidence, form the counterpart to the pervasive influence of the episode's hellish éminences grises. Thus, at the beginning of the tale, the inhabitants of Thrace do not realize that events have been set in motion that will result in unspeakable suffering. In their ignorance, they celebrate the wedding of Tereus and Procne and the birth of Itys with thanksgivings to the gods. Later on, both the poet (6.472-3) and Pandion (6.499) invoke the powers above - the former ironically in commenting on the benighted state of mind that has settled on his characters. ${ }^{36}$ But the most striking appeal belongs to Philomela. After the rape she calls for vengeance in a series of conditional clauses that make the putative cosmic order contingent upon Tereus' punishment $:^{37}$

si tamen haec superi cernunt, si numina divum sunt aliquid, si non perierunt omnia mecum, quandocumque mihi poenas dabis ...

... si silvis clausa tenebor,

implebo silvas et conscia saxa movebo.

audiet haec aether, et si deus ullus in illo est.

(Met. 6.542-8)

What Philomela has suffered goes beyond the scope of theodicy : at issue is not simply the justice of the gods, but their very existence. From her point of view, Tereus' outrage takes on apocalyptic dimensions: everything (omnia) is at stake; but the heavens remain inert as Tereus proceeds brutally to silence his victim. Philomela thus becomes a woman whose universe has failed her ; she is the victim not just of Tereus, but of a hostile or uncaring cosmos in which she had naively placed her faith. ${ }^{38}$

The absence of Olympian gods registers throughout this episode, but nowhere more starkly than at its conclusion. Ovid's culminating metamorphosis (6.667-73) is underdetermined with respect to his own narrative conventions - it is neither requested by any of the protagonists, nor attributed to specific supernatural agency - as well as the broader mythographic tradition. In other accounts, the transformation is attributed to pitying deities in response to the prayers of Pandion's daughters, fleeing Tereus' murderous wrath, even if the metamorphosis does not resolve their mutual hatred (Soph. fr. 581.9-10 Radt). ${ }^{39}$ Aporneothized, Procne then begins her eternal lament over Itys. ${ }^{40}$ There is no such reconciling denouement or tragic redemption in Ovid : no deus ex machina appears in the end to issue a reassurance that some good will prevail. The metamorphoses are left unmotivated on both the divine and the human level, and although Procne is forever marked by her crime (6.669-70) she is never portrayed as experiencing contrition. Any reference to the song of the nightingale, which earlier authors (including Sophocles) interpreted as Procne's dirge for her son, is conspicuously absent from his narrative ${ }^{41}$ Even as birds, Tereus and the two sisters are caught in a dynamic of perpetual, unredeemed hostility. ${ }^{42}$ The forces at work in the Metamorphoses version are not disclosed, but there is a suggestive emphasis on lingering signs of slaughter (neque adhuc de pectore caedis / excessere notae, signataque sanguine pluma est, 6.669-70) and violence (prominet immodicum praelonga cuspide rostrum, 6.673). The following couplet completes the familial extermination by reporting the premature death of the stricken Pandion : 
Hic dolor ante diem longaeque extrema senectae

tempora Tartareas Pandiona misit ad umbras.

(Met. 6.675-6) suggestion of benign divinities overseeing human affairs. ${ }^{43}$ In this tale the supernatural void is filled by the Furies, who right the cosmic order by imposing a causality of crime and punishment - though at a terrible price for all concerned. The notion of the Underworld as a source of narrative energy for pernicious poetry originates in Virgil's Allecto, arguably the first figure of pure evil in Roman literature..$^{44}$ But it is with Ovid's elaboration of this Virgilian idea in the tale of Tereus, Procne and Philomela that the conception finds its most concentrated and haunting articulation.

\section{A poetics of perversion}

In the 1980s and 90s, a divide opened up in scholarship on the Metamorphoses, as an emergent critical movement that might be labeled 'the new formalism' revolutionized conceptions of Ovid's literary artistry by exploring his sophisticated handling of, above all, genre, allusion, and narrative technique ${ }^{45}$ For the first time, the tension (or dialogue) between competing generic forces, Ovid's complex and comprehensive network of allusions to Greek and Latin literary predecessors, and his incessant modulation of the epic narrative voice received the attention they deserved. ${ }^{46}$ Not everyone was pleased by the new emphasis on form. In his review of Stephen Hinds' The Metamorphosis of Persephone, William Anderson stated that "it was daring to pursue the self-conscious Ovid as an insistently programmatic poet, obsessed with generic issues. Because of the limited success of this pursuit, we now perhaps should realize that we can find Ovid more surely in the actual Roman world, as one who raises questions about Augustan values, explores the tragic failures of love, and evokes our sympathy with human feelings. ${ }^{{ }^{47}}$ From a methodological point of view, of course, the two approaches are not mutually exclusive : an episode can be laced with programmatic, intertextual, or generic gestures and still offer a meditation on human experience. ${ }^{48}$ The 'literature' versus 'life' dichotomy that underwrites Anderson's ultimately futile apotropaic intervention has proven too rigid. Interestingly, though, the 'new formalist' movement has yet to grapple with the Tereus, Procne and Philomela episode. Scholars analyzing the interplay of competing generic elements, an approach that works so well for Apollo and Daphne, Dis and Proserpina, and Polyphemus and Galatea, have generally steered clear of this part of the poem. ${ }^{49}$ But here, too, some new formalist probing may help to gain a purchase on Ovid's artistic strategy.

'Omnia turbasti' (6.537): Philomela's succinct summation of the nomological consequences of Tereus' brutality accords with the episode's formal as well as thematic outlook. In the early stages of this gruesome revenge narrative, Ovid deploys a poetics of perversion and paradox that corresponds to and complements his pernicious anthropology. The Metamorphoses is, to be sure, a poem that repeatedly probes and transgresses the putative conventions of the epic genre. Its trademark lapses into the erotic and recurring patterns of 'tragic displacement' attest to a robust heterogeneity of generic elements and narrative energies. But the Tereus, Procne, and Philomela episode offers something more radical: a transmogrification of the generic systems 
initially used to map out the narrative space of the Metamorphoses, a negative dialectics in which epic and elegiac elements distort and pervert one other.

In the first part of the tale, Ovid rather improbably rehearses a full repertory of motifs from his elegiac past. ${ }^{50}$ Upon setting eyes on Philomela, Tereus is smitten with erotic passion; in the course of the subsequent interview with Pandion, his thoughts and conduct conform to advice set forth in the Ars Amatoria. ${ }^{51}$ His initial impulse is to bribe Philomela's nurse and companions ${ }^{52}$ - though, unlike the penny-pinching persona of the Ars Amatoria, he contemplates bribery on a massive scale. ${ }^{53}$ In concealing his erotic agenda behind the more innocent guise of Procne's sisterly sentiment, Tereus operates in the prescribed Ovidian manner. ${ }^{54}$ And just as Ovid had promised (A.A. 1.609-10), the smitten barbarian from Thrace waxes eloquent : facundum faciebat amor (6.469). Tereus bolsters his rhetorical performance with tears (addidit et lacrimas, 6.471), once again according to Ovidian prescription. ${ }^{55}$ And when he finally perjures himself in erotic pursuit (6.506), Ovid's prior authorization of such conduct seems to hover in the air. ${ }^{56}$ But the lighthearted erotic-elegiac discourse that informs this part of the narrative is soon generically deracinated by horrendous sexual violence.

Upon reaching Thrace, Tereus exultingly exclaims vicimus! (6.513), mobilizing a military metaphor often used in erotic contexts. ${ }^{57}$ The application of military imagery and terminology to the affairs of love is a constitutive feature of Roman love elegy, contributing, along with the complementary literary metaphor of servitium amoris, to the genre's complex erotic ideology ${ }^{58}$ Here, however, as the subsequent narrative makes clear, Tereus, son of Mars, 'concretizes' the metaphoric discourse of militia amoris, reducing the subtle gender dialectic of love poetry to simplistic (epic) brutality. Generic dissonance continues with the simile of the eagle and hare (6.516-8), which has its archetype in the Iliad (22.306-11). ${ }^{59}$ The Homeric passage treats the combat of Achilles and Hector; Ovid applies it to Tereus gloating over his helpless victim. After the rape, Philomela will again be equated to defenseless animals and Tereus to bestial predators (6.527-30). ${ }^{60}$ Pavlock neatly sums up the import of these systems of imagery : "Like the epic hero on the battlefield, Tereus treats Philomela as an enemy to be overcome." 61

And still the generic perversions continue. When the brutalized Philomela threatens to disclose Tereus' outrage to the world, he cuts out her tongue :

... radix micat ultima linguae,

ipsa iacet terraeque tremens immurmurat atrae,

utque salire solet mutilatae cauda colubrae,

palpitat et moriens dominae vestigia quaerit.

(Met. 6.557-60)

The severed tongue would be at home on the Homeric battlefield, ${ }^{62}$ but is utterly inappropriate in an erotic context. In the ideal world of the Ars Amatoria communication between lovers, soft murmuring, and tender groaning spice up mutually pleasurable sex. The grotesque image of the dislocated tongue, twitching helplessly on the ground and murmuring into the black earth (terraeque tremens immurmurat atrae) thus emerges as a perverse substitute for the erotic ideal. ${ }^{63}$ Reminiscences of elegiac terminology (dominae, vestigia) reinforce the point. ${ }^{64}$ At the end of the first movement, then, the epic and elegiac registers stand mutually compromised and corrupted. The rehearsal of motifs from the Ars Amatoria reads like a misplaced stocktaking of Ovid's own 'frivolous' literary past. And even the habitually 
prurient narrative voice registers disgust when Tereus, after the mutilation, continues to rape his victim. ${ }^{65}$

\section{An aesthetics of revenge (and metapoetics of literary emulation)}

Generic rupture is less evident in the second half of the tale, which rehearses tragic scenarios that are pertinent to and bear upon Ovid's subsequent tale of Medea. ${ }^{66}$ Like Medea, Procne is caught in a genuinely tragic dilemma, with rage over the misdeeds of her (foreign) husband warring with maternal sentiments. Likewise, her resolve to butcher her son Itys is temporarily weakened by his childlike trust and innocence. But as Procne weighs the tragic choice of siding with sister or husband, she looks upon Philomela, condemned to eternal silence, and launches into a powerful auto-parainesis that contrasts mute sister and prattling son, culminating in the paradoxical realization scelus est pietas in coniuge Terei (6.635). ${ }^{67}$ Now her choice is clear and she proceeds resolutely, murdering Itys in ritual fashion without even averting her eyes (6.642).

In this part of the narrative the logic of revenge is a central thematic preoccupation. In considering the pernicious dynamic of the Tereus tale, it is helpful to distinguish between two forms of revenge: that adhering to the principle of talio ('an eye for an eye') and 'double payback' ('two eyes for an eye', as it were). The logic of the ius talionis has received ample discussion in the literature on revenge tragedy. ${ }^{68}$ Rather less fully acknowledged is the fact that, in certain situations, the symmetry of equal payback may be regarded as beneficial, inasmuch as measured and direct retribution offers a means of conflict resolution that contains the social damage of revenge. ${ }^{69}$ The opposite holds when revenge escalates: the adversaries do not end up on a par, a situation that harbors the potential for further violence, which, if it continues to follow the principle of double payback will eventually result in murder. As Egon Flaig observes, "Das Prinzip der Überbietung in einem Vergeltungs-Ethos führt ... automatisch $\mathrm{zu}$ blutigen Konflikten, die von den Beteiligten nicht mehr stillzustellen sind, die von Dritten beendet werden müssen." 70

31 Considered in this light, the tale of Tereus, Procne and Philomela stands out for its unique combination of perverse symmetry and striking escalation. Procne's scheme of vengeance involves a double strategy that achieves a kind of symbolic parity within a framework of escalating retribution. Before discussing Procne's striving for symmetry, it will be helpful to demonstrate a broader principle of parallelism that underwrites the entire episode. ${ }^{71}$ David Larmour may be conveniently quoted here $::^{72}$

The similarities of the situations are made very clear ... As Tereus flagrat (460), Procne ardet (610). The killing of Itys (furiali caede, 657) strikingly recalls Tereus' treatment of Philomela in the woods : Procne drags Itys off to a remote part of the house, like a tigress with a fawn, just as Tereus took Philomela to a secluded spot, like a wolf with a lamb or an eagle with a dove ; Procne ignores the child's cry of 'mater, mater' (640), just as Tereus paid no attention to Philomela's pleas to her father and to the gods; Procne kills the child with a sword (ense ferit, 641) just as Tereus cut out his victim's tongue ense fero (557). Philomela then slits Itys' throat (643), an action which also recalls Tereus' crime - when he pulled out his sword, Philomela offered him her throat, hoping for death (543-4). Finally, Procne exhibits crudelia gaudia (653) at her triumph over Tereus (himself described as crudelis). 
this overall equilibrium Procne confronts the problem of how to mete out a fitting punishment to Tereus for raping and mutilating her sister. But when it comes to sexual violence, the female of the species is at something of a disadvantage, especially in Ovid's Metamorphoses : only one of the fifty-odd rapes in the epic is perpetrated by a woman. In considering her options, Procne initially ponders the 'obvious' possibilities of glossectomy, blinding or castration (6.616-7, quoted below). But further contemplation leads to an altogether more original path of revenge - and one that restores a sort of hellish parity. By literally 'penetrating' Tereus with his own son she achieves a figurative rape which, like the original crime, throws all familial relations into confusion, while feminizing and grotesquely 'impregnating' her hateful spouse. Procne's notorious response 'intus habes, quem poscis' (6.655) to Tereus' inquiry into their son's whereabouts intimates that she has found a way to pay Tereus back in kind. This can be formulated more graphically: Tereus is not the first person in this episode whose body is penetrated by an unwanted family member. Itys' entombment in the belly of his progenitor is the most satisfyingly symmetrical vengeance that the sisters could have visited upon the incestuous rapist. According to the somatic economy that governs the episode, Procne has achieved a fitting quid pro quo for the violation of her sister. An affirmation of 'poetic justice' is thus clearly at work in Procne's enactment of retribution, and were Tereus an habitually articulate Athenian rather than a crude Thracian he might have reiterated Philomela's pithy denunciation : omnia turbasti.

At the same time, this symmetry necessarily increases the degree of violence (from rape to murder, each time of an utterly innocent victim), and from Sophocles onwards, the tale has been regarded as exemplifying baleful escalation, against the less noxious logic of the talio principle. Such, indeed, would appear to be the concluding observation, probably uttered by the deus ex machina, of Sophocles' Tereus : ${ }^{73}$

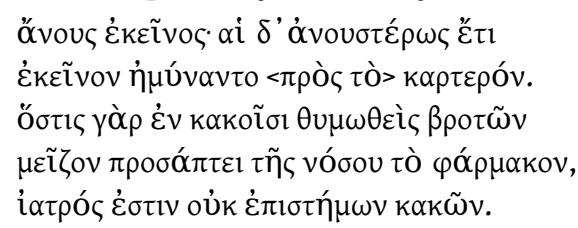

(fr. 589 Radt)

'He [sc. Tereus] was mad; but they [sc. Procne and Philomela] punished him more madly still through violence. For anyone who, when enraged by troubles, ministers a remedy worse than the illness, is a doctor unversed in ills.'

Pandion's daughters do more than equal the score: ritual infanticide and the autophagous annihilation of lineage go well beyond the principle of talio. The surplus is signaled in Procne's initial deliberations, where she fleetingly raises the possibility of exacting vengeance according to the lex talionis, but as quickly rejects it for some deeper satisfaction :

... 'non est lacrimis hoc' inquit 'agendum, sed ferro, sed si quid habes, quod vincere ferrum possit. in omne nefas ego me, germana, paravi : aut ego, cum facibus regalia tecta cremabo, artificem mediis immittam Terea flammis, aut linguam atque oculos et quae tibi membra pudorem abstulerunt ferro rapiam, aut per vulnera mille sontem animam expellam. magnum quodcumque paravi ; quid sit, adhuc dubito.'

(Met. 6.611-9) 
Procne evidently seeks to out-do Tereus. In Ovid's hands, as Barkan well puts it, the tale becomes a "myth of competitive mutilation". ${ }^{74}$ At the close of the episode, as the violence threatens to spin even more out of control, with Tereus about to kill the sisters, the tableau of escalating payback is frozen through unattributed metamorphosis (discussed above).

There is a subtle metaliterary dimension to Procne's diabolical creativity, her principle of escalating repetition, that is picked up by many of Ovid's successors, from Seneca through Shakespeare to Sarah Kane. For Procne is also a reader: as lector she is confronted by a hellish text which, as auctor, she must both reproduce and surpass. The 'text' that she has to face is of course her sister's tapestry, which probably features not images but words. This would likewise appear to be the case for Sophocles' Tereus, as Fitzpatrick well argues : $:^{75}$

While certainty about the nature of Philomela's weaving is impossible, nevertheless the weight of argument appears to be in favour of a text. A pictorial representation risks the serious possibility of discovery by Tereus himself or one of his loyal servants. One might even ask how much graphic detail Philomela included in the depiction of her horrific experiences, whereas, in contrast, a text need only include several significant words.

All this holds true for the Metamorphoses version. Moreover, as Curley points out, purpureas... notas (6.577) is better suited to script than to images. ${ }^{76}$ In any case, Procne reads (legit) and what she reads is a carmenmiserabile (6.582): this is the 'text' she must surpass. Procne's 'aesthetics of revenge', then, her surpassing intratextual appropriation of the pre-written 'text' of mutilation provides an embedded model for subsequent intertextual appropriations of this Ovidian episode. The history of reception shows a distinct tendency of characters in literature written after Ovid to emulate the sisters, in what seems to be a hair-raising enactment of the anxiety of influence, as later authors try to outdo their predecessors by escalating the amount of depicted cruelty and bloodshed. ${ }^{77}$ In a correlation of plot and poetics, the logic of double payback here merges with the desire for originality. The spirited determination of the daughters of Pandion to surpass the criminal conduct of Tereus has lived on above all on the Western stage. ${ }^{78}$ "If revenge attracts the dramatist because, by submitting characters to a scenario, it does as a matter of course what his own writing does perforce, it also attracts him because the revenger is a surrogate artist." 79

\section{Cultural entropy}

If Procne and Philomela emerge as surpassingly successful avengers, they arguably fail as humans - or, more specifically, Athenians. As the episode develops they become progressively estranged from their hallowed cultural origins, from the polis that fashioned itself as the 'civilizer of Hellas'. The daughters of Pandion are drawn into the orbit of Thracian Tereus, and, as already noted, take on infernal attributes. The inescapable assimilation of perpetrator and victim through the act of retribution is a general problem in the ethics of revenge that has been well discussed by Kerrigan.$^{80}$ For Ovid this assimilation has larger anthropological and specifically cultural implications within the world system of his poem.

The Metamorphoses features a complex theodicy, laced with inherent contradictions. As with his treatment of humanity, Ovid's gods can be read across a spectrum of 
conceptual possibilities. Be that as it may, it remains true that the truly outrageous behavior in the epic, the most vicious rapes, the most cruel slaughter, and, with the qualified exception of Ceres, the resort to cannibalism, occur within the mortal domain, when human beings are left to their own devices (a state of affairs already adumbrated in Book 1). In this respect, a crucial feature of the Tereus, Procne and Philomela episode is its aforementioned godlessness, which results in a concomitant expansion of human agency. For the first time, a victim has free rein for retaliation, as she is dealing with a human rather than divine perpetrator. As a consequence, the ethics of revenge become a troublesome issue. New battle-lines are drawn, as the characters lose all moral grounding and are drawn into the perpetration of uncontrolled, orgiastic violence. ${ }^{81}$

This raises the question of how such explorations of humanity's capacity for sickening outrage fit into the poem as a whole. If one reads, with E. A. Schmidt, the half dozen or so anthropogonies that Ovid recounts in the opening book (Prometheus, the four ages, the blood of giants etc.) not just diachronically, but also synchronically - as an attempt, that is, to map out a spectrum of human capabilities, ranging from golden age harmony to the endemic criminality of the iron age - and if one reads the Metamorphoses as a gradual unfolding and illustration of this spectrum, then the Tereus, Procne, and Philomela episode (together with a few, but only a few, others) can be understood as an example of the worst that human beings are capable of, the flip side, as it were, to tales of piety such as Philemon and Baucis. ${ }^{82}$

41 But there is something more going on : Ovid's universalizing anthropology comes with a specific cultural slant. It is not by accident that he probes the most degraded human conduct in the context of Athenian myth. In the Greek imagination, of course, in wastelands such as Thrace, at the edges of the known world, the norms and values of (Greek) civilization did not apply. Instead we find an appalling array of barbarian practices, such as human sacrifice (especially the sacrifice of foreigners, as a perversion of the Greek institution of xenia), female warriors, cannibalism, and so on. In the fifth century, Athenian playwrights began to break down the binary oppositions that underwrite such cultural constructions, facing up to the realization that even in such refined 'blue-bloods' as the daughters of Pandion there lurked savage impulses that the right combination of circumstances could unleash. Avenging agents and victims at the same time, the sisters become emblems of the porous interface between barbarity and civilization in (Athenian) society. More generally, tragedy as a genre allowed the Athenians to articulate their obsession with unregenerate instincts and voice their anxieties about those boundaries that defined the Greek male identity. ${ }^{83}$

Ovid's Metamorphoses reconfigures this thematic from a Roman point of view. In effacing ethical distinctions between the various protagonists, he continues the tragic heritage in undermining conventional Hellenic cultural constructions. ${ }^{84}$ But unlike the Athenian playwrights, who do so from the inside, his perspective is external, part of a broader strategy of 'deconstructing' centers of Greek civilization en route to Roman ascendancy. ${ }^{85}$ 


\section{BIBLIOGRAPHY}

Anderson, W. S. (1989). Review of Hinds (1987). Gnomon 61, 356-8.

Artaud, A. (1938). Le Théâtre et son Double. (Paris).

Barkan, L. (1986). The Gods Made Flesh : Metamorphosis and the Pursuit of Paganism. (Yale).

Bate, J. (1993). Shakespeare and Ovid. (Oxford).

--- (ed.) (1995) Titus Andronicus. The Arden Shakespeare. (London).

Bömer, F. (ed.) (1969-86). P. Ovidius Naso : Metamorphosen, Kommentar. (Heidelberg).

Burnett, A. P. (1998). Revenge in Attic and later tragedy. (Berkeley, Los Angeles, London).

Cazzaniga, I. (1950-1). La saga di Itis nella tradizione letteraria e mitografica Greco-Romana, 2 vols. (Varese).

Clay, J. S. (1989). The politics of Olympus : form and meaning in the major Homeric hymns. (Princeton).

Coleman, R. (ed.) (1977). Vergil : Eclogues. (Cambridge).

Crewe, J. V. (1990). "The violence of drama : towards a reading of the Senecan Phaedra." Boundary 2.17.3, 95-115.

Currie, H. M. (1981). “Ovid and the Roman Stage.” ANRW 2.31.4, 2701-42.

Curley, D. (1997). “Ovid, Met. 6.640 : A Dialogue between Mother and Son.” CQ 47, 320-2.

--- (2003). "Ovid's Tereus : theater and metatheater." 163-97 in A. H. Sommerstein (ed.), Shards from Kolonos: Studies in Sophoclean Fragments. (Bari).

Dobrov, G. (1993). “The tragic and comic Tereus.” AJP 114, 189-234.

Farrell, J. (1992). “Dialogue of Genres in Ovid's 'Lovesong of Polyphemus' (Metamorphoses 13.719-897)." AJP 113, 235-68.

Feeney, D. C. (1993). The gods in epic : poets and critics of the classical tradition. (Oxford).

Fehling, D. (1968). "Nuktos paides apaides : A. Eum. 1034 und das sogenannte Oxymoron in der Tragödie.” Hermes 96, 142-55.

Feldherr, A. and James, P. (2004). "Making the most of Marsyas." Arethusa 37, 75-103.

Ferri, R. (2003). Octavia : a play attributed to Seneca. (Cambridge).

Fitzpatrick, D. (2001). “Sophocles’ Tereus.” CQ 51, 90-101.

Flaig, E. (1998). Oedipus : tragischer Vatermord im klassischen Athen. (Munich).

Ford, A. (1992). Homer : the poetry of the past. (Ithaca).

--- (1997). “Epic as genre." 396-414 in I. Morris and B. Powell (eds.) A new companion to Homer. (Leiden).

Friedrich, W. H. (1956). Verwundung und Tot in der Ilias. (Göttingen).

Fuhrmann, M. (1994). Review of Ransmayr (1988) [above, n. 1]. Arbitrium 7, 250-4.

Gehrke, H.-J. (1987). "Die Griechen und die Rache : ein Versuch in historischer Psychologie.” Saeculum 38, 121-49. 
Gildenhard, I. and Zissos, A. (1997). Review of W. Anderson (ed.), Ovid's Metamorphoses Books 1-5. BMCR 1997.9.11.

--- (1999). "Somatic Economies : Tragic Bodies and Poetic Design in Ovid's Metamorphoses." 162-181 in P. Hardie, A. Barchiesi, S. Hinds (edd.), Ovidian Transformations. Essays on Ovid's Metamorphoses and its reception. (Cambridge).

--- (2000). “Inspirational Fictions : Autobiography and Generic Reflexivity in Ovid's Proems." Greece \& Rome 47 (2000), 67-79.

--- (2004). “Ovid's 'Hecale' : Deconstructing Athens in the Metamorphoses.” JRS 94, 47-72. Graziosi, B. and Haubold, J. (2005). The resonance of epic. (London).

Hamburger, K. (1965). Von Sophokles zu Sartre. Griechische Dramenfiguren antik und modern. (Stuttgart).

Hardie, P. H. (1993). The Epic Successors of Virgil. (Cambridge).

Haubold, J. (forthcoming). "Athens and Aegina : Herodotus 5.82-9”.

Hershkowitz, D. (1998). The madness of epic : reading insanity from Homer to Statius. (Oxford).

Hinds, S. (1987). The Metamorphosis of Persephone. (Cambridge).

Jacobsen, G. A. (1984). “Apollo and Tereus : Parallel Motifs in Ovid's Metamorphoses.” CJ 80, 45-52. Jens, W. (ed.) (1971). Die Bauformen der griechischen Tragödie. (Munich).

Kaufhold, S. D. (1997). “Ovid's Tereus : Fire, Birds and the Reification of Figurative Language.” CP 92, 66-71.

Kennedy, D. (1993). The Arts of Love : Five Studies in the Discourse of Roman Love Elegy. (Cambridge).

Kerrigan, J. (1996). Revenge tragedy: Aeschylus to Armageddon. (Oxford).

Klockner, A. (2005). "Mordende Mütter. Medea, Prokne und das Motiv der furchtbaren Rache im klassischen Athen." 247-64 in G. Fischer and S. Moraw (edd.), Die andere Seite der Klassik. Gewalt im 5. und 4. Jahrhundert v. Chr. (Stuttgart).

Knox, P. (1986). Ovid's Metamorphoses and the Traditions of Augustan Poetry. (Cambridge).

--- (ed.) (1995). Ovid Heroides : Select Epistles. (Cambridge).

Lajarrige, J. (ed.) (2003). Lectures croisées de Christoph Ransmayr : Le dernier des mondes. (Paris).

Larmour, D. H. J. (1990). “Tragic Contaminatio in Ovid's Metamorphoses : Procne and Medea ; Philomela and Iphigeneia (6.424-674) ; Scylla and Phaedra (8.19-151).” ICS 15, 131-41.

Martindale, C. (1993). Redeeming the text : Latin poetry and the hermeneutics of reception. (Cambridge). Mossman, J. (1995). Wild Justice : a Study of Euripides' Hecuba. (Oxford).

Newlands, C. (1997). “The Metamorphosis of Ovid's Medea." 178-208 in J. J. Clauss and S. I. Johnson (edd.), Medea. (Princeton).

Newman, J. (1994). “'And Let Mild Women to Him Lose Their Mildness' : Philomela, Female Violence and Shakespeare's The Rape of Lucrece." Shakespeare Quarterly 45, 304-26.

Nicoll, W. S. M. (1980). “Cupid, Apollo, and Daphne (Ovid, Met. 1.452ff.).” CQ 30, 174-82.

Norden, E. (1913). Agnostos Theos. (Leipzig and Berlin).

Otis, B. (1966). Ovid as an epic poet. (Cambridge). 
Pavlock, B. (1991). “The Tyrant and Boundary Violations in Ovid's Tereus Episode.” Helios 18, $34-48$

Redmond, J. (ed.) (1991). Violence in drama. (Cambridge).

Richlin, A. (1992). "Reading Ovid's Rapes." 158-79 in ead. (ed.), Pornography and Representation in Greece and Rome. (Oxford).

Schiesaro, A. (2003). The passions in play: Thyestes and the dynamics of Senecan drama. (Cambridge).

Schlesier, R. (1988). “Die Bakchen des Hades : dionysische Aspekte von Euripides' Hekabe.” Metis 3, 111-35.

Schmidt, E. A. (1991). Ovids poetische Menschenwelt : die Metamorphosen als Metapher und Symphonie. (Heidelberg).

Seaford, R. (1987). “The Tragic Wedding.” JHS 107, 106-130.

Segal, C. (1994). "Philomela's web and the pleasures of the text : reader and violence in the Metamorphoses of Ovid." 257-80 in I.J.F. de Jong and P. Sullivan (edd.), Modern Critical Theory and Classical Literature. (Leiden, New York, Cologne).

Thomas, E. (1964). “Variations on a Military Theme in Ovid's Amores.” G\&R 11, 151-65.

Thome, G. (1993) Vorstellungen vom Bösen in der lateinischen Literatur : Begriffe, Motive, Gestalten. (Stuttgart).

Winnington-Ingram, R. P. (1980). Sophocles : an interpretation. (Cambridge).

\section{NOTES}

1. Ransmayr's Die letzte Welt. Mit einem Ovidischen Repertoire (Nördlingen 1988) first appeared in the series Die Andere Bibliothek, edited by Hans Magnus Enzensberger; we cite from the English translation of J. E. Woods (New York 1990). The initial public response to the novel was strong, and secondary literature is growing apace : see, e.g., the contributions in Lajarrige (2003).

2. Some of the characters Cotta encounters are rationalizations of Ovidian myths (Lycaon, the werewolf, Arachne, the deaf-mute weaver); others are intertextual hybrids such as Dis: Ransmayr's god of death is a master from Germany, and the allusion to Paul Celan and his haunting poetry on Auschwitz is symptomatic of the novel's prevailing narrative ethos.

3. See Fuhrmann (1994), on the paradoxical evocation of the "four last things" of Christian theology (Death, Judgement, Heaven, Hell) in the title of a work of unremitting nihilism.

4. The basic elements of the Ovidian version appear to have been present already in Hesiod (fr. $312 \mathrm{MW}$ ) and perhaps even Homer (Od. 19.518-23, where, however, the language is ambiguous : the Scholiast ad loc. and most modern critics understand an accidental infanticide). But the myth evidently achieved its classic pre-Ovidian articulation with Sophocles' Tereus, a tragedy that has survived in substantial fragments (usefully analyzed by Fitzpatrick [2001]). The myth was also popular with Roman theater goers : Accius' Tereus (probably more than a mere translation of the Sophoclean play) seems to have been "a stage favorite of the late republic" (Otis [1966], 377 ; cf. Cic. Att. 16.2.3 and 16.5.1). See also Coleman (1977) on Ecl. 6.78 and more generally Cazzaniga (1950-1).

5. See the very end of The Last World: "One thing drew Cotta into the mountains - the only inscription he had not yet discovered ... He was sure it would be a small banner - after all, it carried only two syllables. When he stopped to catch his breath, standing there so tiny under the overhanging rocks, Cotta sometimes flung those syllables against the stone, and answered, Here! 
as the echo of his shout came back to him. For what reverberated from the walls - broken and familiar - was his own name."

6. Ovid's own conclusion links afterlife and reading: Met. 15.878-9 ore legar populi, perque omnia saecula fama / (siquid habent veri vatum praesagia) vivam. For a perceptive discussion of Ovid's epilogue and its metaliterary agenda see Hershkowitz (1998), 188-90.

7. See Gildenhard and Zissos (1999), 164-70.

8. Richlin (1992), 158 ; cf. also Segal (1994).

9. Chaucer : LGW 7.158-64 ; Gower : Confessio Amantis 5.5551-6074. Other early contributions to this poetic tradition include Dante Purg. 9.13-5 and Petrarch's poem Solo e pensoso.

10. The classic study is Artaud (1938) ; see also more recently Crewe (1990) and the contributions in Redmond (1991).

11. Shakespeare, Titus Andronicus, with Bate (1993) and (1995); Seneca, Thyestes, with Schiesaro (2003) ; Correr, Procne (1427); Wertenbaker, The Love of the Nightingale (1989); Kane, Cleansed (1998).

12. We intend to explore this history of reception in more detail in a subsequent article.

13. The episode opens suggestively with the invasion of Attica by an unspecified foreign enemy (6.422-3, discussed further below, n. 18), the first concrete treatment of human warfare in the poem.

14. Haubold (forthcoming). See further Clay (1989) ; Ford (1992) and (1997) ; Graziosi and Haubold (2005).

15. See Gildenhard and Zissos (2004).

16. For the methodological principle see Jens (1971), xv ("die Variationen der Schriftsteller [enthalten] häufig die treffendsten Deutungen des Urbilds"), with an unparticularized reference to Käte Hamburger, most likely Hamburger (1965) ; similarly Martindale (1993).

17. Sophisticated treatments of this narrative stretch include Feeney (1993), 190-4 on Arachne ; Feldherr and James (2004) on Marsyas.

18. This invocation of a conflict between an unidentified 'barbarian' army from across the sea is curious; Apollod. 3.14.8 makes Athens' war with Labdacus, king of Thebes, the occasion of the alliance with Tereus.

19. Even Ovid's assertion of Tereus' divine paternity at Met. 6.427 et genus a magno ducentem forte Gradivo is somewhat more equivocal than, e.g., Hyg. Fab. 45.

20. See Norden (1913), 143-76.

21. Contrast Met. 4.758-9 taedas Hymenaeus Amorque / praecutiunt (Perseus and Andromeda) and 12.215 ecce canunt Hymenaeon (Pirithous and Hippodamia) - though both weddings devolve into violence before reaching a satisfactory conclusion. The only untroubled union over which the god explicitly presides in the Metamorphoses is that between Iphis (turned into a man just in time) and Ianthe (9.796-7) - which, however, leads to the tragedy of Orpheus and Eurydice, a union that Hymenaeus is unable to bless (10.1-8).

22. The epithet pronuba for Juno is rare anyway in the Metamorphoses, recurring only once (9.762), where Telephusa, worried sick about the imminent same-sex marriage of her cross-dressing daughter Iphis, wishes her away. Gratia only occurs here. For the notion of a wedding made in hell see already Ov. Her. 2.117 pronuba Tisiphone with Knox (1995), 133 who traces the idea back to Juno's curse on Aeneas' wedding to Lavinia, citing Virg. Aen. 7.319 'Bellona manet te pronuba'. For the perversion of wedding in Greek tragedy, see Seaford (1987); for its importation into Roman epic via “Allecto's pullulating fertility of evil", Hardie (1993), 90. Further material is collected by Ferri (2003), 131-2 on [Sen.] Oct. 23-4 : illa, illa meis tristis Erinys / thalamis Stygios praetulit ignes.

23. See also its appearance as funereus bubo at 10.452-3 (just before Myrrha's incest) and as Stygius ... bubo at 15.791 (Caesar's assassination); cf. Virg. Aen. 4.462 solaque culminibus ferali carmine bubo (with Serv. ad loc.: "sola contra genus posuit ... referens ad avem"); Ibis 223-4 sedit in adverso nocturnus culmine bubo, / funereoque graves edidit ore sonos : the marriage is cursed. 
24. Met. 6.455-7, 460, 466, 480, 490-3 with Kaufhold (1997), 67.

25. Met. 4.481-2 Tisiphone ... sumit ... facem; and 508-9 tum face iactata per eundem saepius orbem / consequitur motis velociter ignibus ignes.

26. The Bacchic rites and Procne's Bacchic disguise appear to have featured in Accius' version (Acc. fr. 647 W with Dobrov [1993], 206), and could ultimately derive from Sophocles. If so, then Ovid's hellish reconceptualization of an inherited element (and perhaps alteration of its narrative function) would be thrown into even sharper relief.

27. Curley (1997) suggests that Ovid has provided a verbal reminiscence of Eur. Bacch. 1118-20 in Itys' geminated cry 'mater! mater!' at 6.640 .

28. See Newman (1994), 317-8.

29. The Furies are the offspring of Night (Met. 4.451-2 sorores / Nocte ... genitas, grave et implacabile

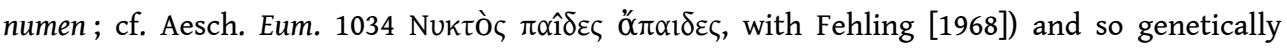
qualified to preside over plots of dissimulation that enshroud human beings in the darkness of incomprehension. Appropriately, Ovid, at two crucial junctures, refers to his characters' benighted state of mind. Commenting on Tereus' tearful performance which wins him credit with Pandion and Philomela, the poet exclaims : pro superi, quantum mortalia pectora caecae / noctis habent! (6.472-3) - an ironic reference to the gods in Heaven when the powers at work in his narrative come from Hell. And at the end of the episode, when Tereus calls for his already ingested son, Ovid wryly observes tantaque nox animi est (6.652).

30. See e.g. Pac. 422-3 $R^{2}$ Flexanima tamquam lymphata aut Bacchi sacris / commota, which inspired Catullus' description of maenads at 64.254-5 (Quae tum alacres passim lymphata mente furebant / Euhoe bacchantes, euhoe capita inflectentes.) and was surely on Virgil's mind as well.

31. Tisiphone's intervention in Met. 4, which led to the 'Bacchic' frenzy of Ino and Athamas, elicits a satisfied smile from Juno : 'euhoe Bacche!' sonat : Bacchi sub nomine Iuno / risit et 'hos usus praestet tibi' dixit 'alumnus!' (4.523-4). Inasmuch as Juno's hellish plot is modeled upon the example of Dionysus, the episode thus offers an 'etiology' of the conflation of tragedy, epic, and hell, a triangular configuration that underwrites much 'Silver' Latin poetry. It is worth noting further reminiscences of the Ino and Athamas episode that reinforce the hellish milieu of the Tereus, Procne and Philomela tale : 4.502 caecae... oblivia mentis $\sim 6.472-3$ quantum mortalia pectora caecae / noctis habent ; 4.504 aere cavo (the pot in which Tisiphone brews her poisonous stew) 6.645 cavis ... aenis (the pot in which Procne boils up Itys); 4.503 caedis amorem and 506 furiale venenum 6.657 sparsis furiale caede capillis ; 4.517 bracchia tendentem (Learchus reaching out to his murderous father) 6.639 tendentemque manus (Itys reaching out to his murderous mother); 4.471 in facinus traherent Athamanta furores and 512 furibundus $~ 6.480$ ciboque furoris and 595 furiisque agitata doloris.

32. Bömer (1969-86) on Met. 4.506.

33. See Schlesier (1988), especially 124-5. Mossman (1995), 190 n. 56. For the role of the furies in Greek tragedy, esp. Aeschylus, see Winnington-Ingram (1980), 206-9.

34. Schlesier (1988). In fact, Ovid himself, who recounts the fate of Hecuba in book 13, links Tereus and Polymestor by shared use of the epithet Odrysius (6.490 and 13.554, the only two occurrences in the poem).

35. Indeed, one could argue that Tereus here merely repeats an act of invocation performed earlier by Philomela's severed tongue, whose murmuring into the dark earth (6.558 ipsa [sc. lingua] iacet terraeque tremens immurmurat atrae) suggests an invocation of the demons of the underworld. This impression is reinforced by the use of ater, a word that has special affinities with the nether realms: see Bömer (1969-86) on 3.63 with further literature. Likewise, the subsequent simile that compares the tongue to the twitching tail of a bisected snake (Met. 6.559-60) establishes a hellish connection on the level of imagery. Snakes are the most conventional literary accoutrement of the Erinys, and Ovid's own Furies are particularly wellendowed : e.g. 4.454 deque suis atros pectebant crinibus angues ; 474-5 Tisiphone canos, ut erat, turbata 
capillos / movit et obstantes reiecit ab ore colubras ; 491 nexaque vipereis distendens bracchia nodis; 495-6 inde duos mediis abrumpit crinibus angues / pestiferaque manu raptos immisit. See further Richlin (1992), 164.

36. See above n. 29.

37. The futility of appealing to the gods above is already indicated at 6.525-6, where Ovid, in a telling syntactical disjunction, renders Philomela's verbal protest during the rape via the ablative absolute : frustra clamato saepe parente, / saepe sorore sua, magnis super omnia divis.

38. As Ferri (2003) on [Sen.] Oct. 911-3 observes, "the cry that gods no longer exist and all values are overturned is a typically tragic (especially Euripidean) recrimination, pronounced by characters suffering abuse and injustice."

39. Divine compassion features at Hyg. Fab. 45 ; cf. Apollod. 3.14.8.

40. There is precedent in Euripides : cf. Mossman (1995), 201 (on the absence of a deus ex machina in the Hecuba): "Euripides did not want a god in this strangely godless play; he wanted an embittered, confusing ending, with none of the certainty and order which a theophany would have introduced, however grim the god's message; he wanted to show a world of human confusion and doubt, with only the merest hint of a divine hand at work, and to allow room for argument on every issue raised in the latter part of the play."

41. In fact Ovid avoids specifying which sister becomes the nightingale and which the swallow (a matter on which there was confusion in the tradition : see Bömer [1969-86] ad loc.).

42. The transformation recalls that of Arachne, who likewise retains a single-minded determination after undergoing metamorphosis and is literally 'sus-pended' (Met. 6.136 atque ita 'vive quidem, pende tamen, inproba' dixit [sc. Minerva] ; cf. 6.667-8 corpora Cecropidum pennis pendere putares: / pendebant pennis!).

43. Even in Ransmayr's The Last World, the transformation of the three human beings into birds provides reconciling closure to the sociopathic violence.

44. See more generally Thome (1993).

45. For 'new formalism' see Gildenhard and Zissos (1999).

46. Early impetus for this critical movement came from the seminal studies of Knox (1986) and Hinds (1987).

47. Anderson (1989), 358.

48. For further discussion of this point, see Gildenhard and Zissos (1997).

49. Apollo and Daphne: Nicoll (1980); Dis and Proserpina: Hinds (1987); Polyphemus and Galatea : Farrell (1992). As Johannes Haubold reminds us, the interplay of erotic and epic motifs (and the notion of sex as continuing epic power play by different means) is of course as old as Homer.

50. Jacobsen (1984) notes that the Tereus and Procne episode reiterates motifs and imagery from that of Apollo and Daphne; for our analysis the crucial point - apart from the recontextualization of these motifs in a hellish narrative milieu - is the marked elegiac affiliations of the earlier episode, for which see, e.g., Gildenhard and Zissos (2000).

51. This elegiac overlay emerges through comparison with Accius' account of Tereus' instantaneous 'barbarian' resolve (frr. 639-42 W): Tereus indomito more atque animo barbaro / conspexit in eam; amore vecors flammeo, / depositus, facinus pessimum ex dementia / confingit. The difference in treatment is all the more significant in that Ovid would appear to be adapting Accius here : see Currie (1981), 2725.

52. Cf. Met. 6.461-3 impetus est illi comitum corrumpere curam / nutricisque fidem, nec non ingentibus ipsam / sollicitare datis totumque inpendere regnum with A.A. 1.351-5 sed prius ancillam captandae nosse puellae / cura sit : accessus molliet illa tuos ... hanc tu pollicitis, hanc tu corrumpe rogando.

53. Compare A.A. 1.399-412 where Ovid counsels the reader to stay away from potential lovers on dates, such as birthdays, when significant expenditure might be called for, with Tereus' willingness to sell his entire kingdom (totum... impendere regnum, Met. 6.463). 
54. Cf. A.A. 1.489-90 neve aliquis verbis odiosas offerat auris, / qua potes, ambiguis callidus abde notis.

55. Cf. A. A. 1.659-60 et lacrimae prosunt ; lacrimis adamanta movebis : / fac madidas videat, si potes, illa genas.

56. Cf. A. A. 1.633-6 Iuppiter ex alto periuria ridet amantum / et iubet Aeolios inrita eferre Notos. / per Styga Iunoni falsum iurare solebat / Iuppiter : exemplo nunc favet ipse suo. That which is condoned in an erotic context is unacceptable in an epic one. What Achilles, the archetypal epic hero, thinks about such an ethics of duplicity in the context of an embassy, he states clearly to Odysseus, Ajax and Phoenix in 'the' embassy-scene of ancient epic, Il. 9.312-3 ("'For hateful in my eyes, even as the gates of Hades, is that man who hides one thing in his mind and says another..."'). See further Aesch. fr. 609a Mette, for the two different shapes of the hoopoe, preserving Tereus' double nature and ability for theatrics and disguise.

57. See Bömer (1969-86) ad loc. Vicimus as an exclamation of erotic triumph, also used by the sexually aggressive Salmacis in her moment of triumph with Hermaphroditus at Met. 4.356, harks back to Prop. 1.8.28.

58. Cf. Thomas (1964), 154 : "Tibullus and Propertius first gave the topos its full significance as a literary metaphor and treated it as a connected theme ... But it was Ovid who really understood the metaphor and perfected it, giving it a playful connotation and divesting it of the earnestness and solemnity it had possessed in the earlier poets." On the discourse of Roman love elegy, see Kennedy (1993).

59. See Pavlock (1991), 47 n. 10.

60. The terms of comparison again have precursors in martial epic. Compare, for example, Achilles pursuit of Hector at Hom. Il. 22.139-42 ("as a falcon in the mountains, swiftest of winged creatures, swoops lightly after a trembling dove : she flees before him, and, hard by, he darts at her with shrill cries, and his heart bids him seize her") and his subsequent remark that "wolves and lambs have no hearts of concord, but are evil-minded continually one against the other..." (22.263-4).

61. Pavlock (1991), 36, likening Tereus' “misapplication of virtus" here to Sextus Tarquinius' assault on Lucretia in the Fasti.

62. Cf. the description of Diomedes' spear severing Pandarus' tongue at Il. 5.292-3, deemed by Friedrich (1956), 23-4 to be a typical Homeric touch of "Scheinrealismus".

63. Compare two passages leading to climax : A.A. 2.723-4 accedent questus, accedet amabile murmur / et dulces gemitus aptaque verba ioco and A.A. 3.795-6 nec blandae voces iucundaque murmura cessent / nec taceant mediis improba verba iocis.

64. Pavlock (1991), 40.

65. Expressed via the authorial parenthesis vix ausim credere (6.561).

66. Larmour (1990), 131-4 ; Newlands (1997), 192-5.

67. Similar paradoxes at 3.5 facto pius et sceleratus eodem; 7.339 his ut quaequae pia est hortatibus inpia prima est ; 9.407-8 ultusque parente parentem / natus erit facto pius et sceleratus eodem.

68. Kerrigan (1996) offers a useful overview.

69. Flaig (1998), 105-6, concluding that "[d]ie Talio ist demnach eine von mehreren soziologischen Möglichkeiten, die Vergeltung so einzugrenzen, daß sie der Gemeinschaft nicht gefährlich wird."

70. Flaig (1998), 107. He goes on to show the social relevance of the 'double payback' principle in Greek life and thought, from Hes. Op. 709-11 to the law court speeches of fourth-century Athens, within wider ethnographic parameters (108-11).

71. The episode manifests a conspicuous symmetry in narrative structure. After the prologue, which is marked off stylistically from the rest of the story, two balanced narrative movements follow. The first treats Tereus' brutalization of Philomela ; the second, clearly separated in time note the temporal demarcation at 6.571 signa deus bis sex acto lustraverat anno - provides the counterpoint in which Procne exacts retribution. 
72. Larmour (1990), 133-4. It may be worth pointing out in addition that Itys' affectionate disposition towards Procne recalls Philomela's towards her father at the beginning of the story (6.624-8 and 475-9 respectively). See also Gildenhard and Zissos (1999), 164-70 for further formal symmetries in the first and second half of the tale : Procne retaliates in style.

73. The god in question has been variously identified as Ares, Athena and Hermes: see Fitzpatrick (2001), 99.

74. Barkan (1986), 244.

75. Fitzpatrick (2001), 97-8, noting in addition that in Shakespeare's Titus Andronicus, the more severely disabled Lavinia uses a staff to inscribe on the ground "Stuprum - Chiron - Demetrius" (4.1.77).

76. Curley (2003), 193-4 adducing OLD s.v. nota 3-9 and noting that the monochromatic implications of purpureas also favor the textual over the pictorial ; cf. contra Pavlock (1991), 42.

77. See, e.g., Sen. Thy. 56-7 Thracium fiat nefas / maiore numero with Schiesaro (2003), 70-8; Shakespeare, Titus Andronicus 2.3.41 "“A craftier Tereus, cousin, hast thou met ... "' and 5.2.194-5 "'For worse than Philomel you used my daughter, / And worse than Progne I will be avenged" with Bate (1993), 108-9.

78. See above, n. 11.

79. Kerrigan (1996), 17. See also Schiesaro (2003), 85-98 on the figure of Atreus in Seneca's Thyestes.

80. See Kerrigan (1996), especially his useful synopsis (6) : "Evidently, the structure of vengeance excites more than a visceral thrill. Ethical exchanges are implicit in the simplest plot. In that primal action on the open stage, the symmetry of revenge is inseparable from a dramatic irony which complicates the moral situation of the revenger. This irony takes effect regardless of authors' views; whether or not they approve of vengeance, the complications will register. For when B, injured by A, does to A what A did to him, he makes himself resemble the opponent he has blamed, while he transforms his enemy into the kind of victim he once was." For revenge in ancient Greece and Greek tragedy, see e.g. Gehrke (1987) and Burnett (1998).

81. E negativo, the tale would appear to suggest that the gods in Ovid's epic do have some sort of moral function, even if their own morality is deeply compromised.

82. See Schmidt (1991).

83. It is worth noting that the tragic view of the daughters of Pandion differs from that often found in other media of mythic representation. Klöckner (2005) discusses a sculpture group of Procne and Itys on the Athenian Acropolis, evidently a positive depiction of the infanticide. Likewise Demosthenes, in his epitaphios for the dead of Chaironeia (60.28), cites Procne and Philomela as praiseworthy exempla of Athenian resistance against barbarian hubris.

84. Cf. Larmour (1990), 134: "The implication ... is that the barbarian/Greek antithesis is of dubious validity. Procne and Philomela, from Athens, are not so different from Thracian Tereus after all."

85. See Gildenhard and Zissos (2004) for the argument.

\section{ABSTRACTS}

This article offers a detailed examination of Ovid's Tereus, Procne and Philomela épisode (Met. 6.412-674). Our focus on the tale's literary and thematic profile, within its history of reception 
(from Seneca's Thyestes through Shakespeare's Titus Andronicus to Ransmayr's The Last World). We consider four interrelated features of Ovid's narrative that have attracted the attention of subsequent artists, but have yet to find full acknowledge-ment and appreciation in the scholarly literature: (1) a figuring of hell on earth; (2) a poetics of perversion; (3) an aesthetics of vengeance (and metapoetics of literary emulation) ; and (4) an entropy of culture.

\section{INDEX}

Mots-clés: Ovid, Metamorphoses, Ransmayr, The Last World, Sophocles, Tereus, Procne, Philomela, Itys, Athens, Thrace, culture, barbarity, underworld, hell, furies, rape, mutilation, infanticide, revenge ethics, talio, escalation of violence, new formalism, poetics, metapoetics, literary emulation, reception

\section{AUTHORS}

\section{INGO GILDENHARD}

University of Durham

ingo.gildenhard@durham.ac.uk

\section{ANDREW ZISSOS}

University of California, Irvine

pzissos@uci.edu 